\title{
Zihinsel Gelişim İlkelerine Göre İlkokul Birinci Sınıf Matematik Ders Kitabındaki Etkinliklerin İncelenmesi
}

\author{
Hatice BOZKURT \\ Gaziantep Şehit Nafi Kıvanç İlkokulu, Gaziantep, hatice.44.bzkrt@gmail.com \\ ORCID NO: 0000-0001-8345-3950
}

\begin{abstract}
Begüm ÖZMUSUL
Gaziantep Üniversitesi, Nizip Eğitim Fakültesi, Matematik ve Fen Bilimleri Eğitimi Bölümü bgmozmsl@gmail.com, ORCID NO: 0000-0003-0163-5406
\end{abstract}

\begin{abstract}
ÖZET
Bu çalışmanın amacı ilkokul birinci sınıf matematik ders kitabında verilen etkinlikleri zihinsel gelişim ilkelerine göre incelemektir. Çalışmada doküman incelemesi yöntemi kullanılmıştır. Doküman olarak 2020-2021 eğitimöğretim yılında devlet okullarında ders kitabı olarak kullanılan ilkokul matematik 1 ders kitabı kullanılmıştır. Veriler betimsel analiz yöntemi kullanılarak analiz edilmiştir. Betimsel analizlerde Bruner (1966)'da verilen zihinsel gelişim ilkeleri teorik çerçevesi kullanılmıştır. Bu çerçeve yardımıyla ders kitabında verilen etkinlikler eylemsel, imgesel ve sembolik düzey kodlarına göre sınıflandırılmıştır. İncelenen etkinliklerde bu temsillerden birisi, ikisi veya üçünün bir arada kullanım durumlarına bakılmıştır. Araştırmadan elde edilen bulgulara göre ders kitabında tüm öğrenme alanlarında daha çok imgesel düzeyde etkinliklerin olduğu sonucuna varılmıştır. İmgesel düzeyden sonra en çok sembolik düzeyde etkinliklerin olduğu görülmüştür. Eylemsel-imgesel düzeyleri içeren etkinliklerin en fazla geometri öğrenme alanında ve en az ise sayılarla işlemler alt öğrenme alanındaki kazanımlarında olduğu görülmüştür. Tüm öğrenme alanlarında eylemsel-sembolik düzeyleri içeren etkinliklere yönelik herhangi bir bulguya rastlanmamıştır. Birden fazla düzeyin bir arada olduğu etkinliklerin yaklaşık yarısı eylemsel-imgesel-sembolik düzeylerin birlikte olduğu etkinlikler olduğu sonucuna varılmıştır. Üç temsilin bir arada kullanıldığı etkinlikler öğrencilerin kavramı çok yönlü öğrenmelerine katkıda bulunabilir. Bu yönüyle Bruner'in zihinsel gelişim ilkelerindeki hiyerarşik sıra bu bulguyla örtüşmektedir. İlkokul 1. sınıf öğrencilerinin öğrenme sürecinin başında olmaları kaçınılmaz olarak hemen hemen her kazanımın onların zihinsel gelişim açısından Bruner'in modelindeki hiyerarşik düzeylerinin en alt basamağından başlanmasının daha uygun olacağı söylenebilir.
\end{abstract}

Anahtar kelimeler: İlkokul 1 matematik ders kitab1, Bruner, Zihinsel gelişim ilkeleri, Etkinlik

Year 5/ 2021, Volume-5, Issue-2 | WWW.ispecjournal.org 


\title{
Investigation of Activities in Primary School Mathematics Course Book According to the Intellectual Development Principles
}

\begin{abstract}
The aim of this study is to examine the activities given in the primary school first grade mathematics textbook according to the principles of intellectual development. Document analysis method was used in the study. Primary school mathematics 1 textbook, which is used as a textbook in public schools in the 2020-2021 academic year, was used as the document. The data were analysed using descriptive analysis method. In the descriptive analysis, the theoretical framework of intellectual development principles given in Bruner (1966) was used. With the help of this framework, the activities given in the textbook were classified according to the codes of enactive, iconic and symbolic modes. In an activity, the use of one, two or three of these modes together was examined. According to the findings obtained from the research, it was concluded that there are mostly activities involving iconic mode in all learning areas in the textbook. Symbolic modes are the most common form of mode after iconic modes. It is seen that the activities including the enactive-iconic modes are mostly in the field of learning geometry and the least number of operations outcomes. It has been found that the proportion of activities involving enactive-iconic-symbolic levels activities are high. Activities where three modes are used together can contribute to students' multifaceted learning of the concept. In this respect, the hierarchical order in Bruner's intellectual development principles coincides with this principle. It can be said that it would be more appropriate to start from the lowest level of the hierarchical level in Bruner's model in terms of almost every acquisition in terms of intellectual development of primary school 1st grade students being at the beginning of the learning process. In this respect, it can be suggested that the textbooks should be rearranged and teachers design their learning processes in this direction.
\end{abstract}

Keywords: Primary school 1 math textbook, Bruner, Intellectual development principles, activity

\section{GíRiş}

Yapılandırmacı yaklaşım öğrencilerin öğrenme sürecinde aktif olmalarını, yaparak ve yaşayarak sürece dâhil olabilecekleri ortamlar oluşturulmasının öneminin altını çizmektedir (Lerman, 1989; Steffe \& Gale, 1995). Özellikle erken yaşlardaki öğrencilerin psikomotor becerilerinin gelişmesi açısından da yaparak ve yaşayarak öğrenmenin gerekli olduğunu ortaya koyan çalışmalara rastlamak mümkündür (Şahin, 2010). Ayrıca temel eğitim döneminde öğrenmenin somut deneyimlerden başlaması gerektiğinin altını çizin birçok teori vardır. Bunların başında Piaget'nin bilişsel gelişim kuramı (1999), Kolb’un yaşantısal öğrenme kuramı (1984) gibi teoriler öğrenmeyi somut deneyimlerden başlatılması gerektiğinin altını çizmektedir. Bruner'de (1966) öğrenmelerin aktif yaşantı sonrası, zihinde resmedilmesi, görsellere taşınması ardından da bu bilgilerin matematiksel dil yani sembolik gösterim kullanılmaya evrilmesi gerektiği vurgulanmaktadır.

Year 5/ 2021, Volume-5, Issue-2 | WwW.ispecjournal.org 


\subsection{Bruner’in Bilişsel Gelişim Dönemleri}

Bruner'e (1966) göre, bir kavramı yeni öğrenen öğrenciler için bilişsel gelişim sürecinin üç aşamada ilerlemektedir: (1) Eylemsel (somut nesneler üzerindeki eylemler), (2) İmgesel (resimli görseller) ve (3) Sembolik (soyutlamalar, kelimeler, sayılar) (Smith, 2001). Böylelikle Bruner, çocukların nasıl düşündükleri kadar, nasıl öğrendiklerine ve öğrenmeleri için öğrenme sürecinin nasıl yapılandırılması gerektiğine odaklanmıştır (Martin, 2003; Smith, 2001).

Eylemsel düzey: Bu düzeyi Bruner (1966), öğrenmenin ilk basamağı olarak ifade etmiştir. Bu aşamada öğretmenlerin çocukların öğrenmelerini nesneler üzerinden (manipülatifler) dokunarak deneyimlemeleri için firsatlar sağlaması gerekir (Gallestein, 2005). Öğretmenler, manipülatifler ve diğer materyallerle çalışırken çocukları dikkatle gözlemleyerek öğrenmeleri kavramlarla bağlantılar kurulması kolaylaştırabilirler (Dienes, 1967). Ancak manipülatifler çocukların gelişim düzeyine uygun olması önemlidir (Smith, 2001).

Imgesel düzey: Öğrencilerin İşitsel, kinestetik veya görsel ipuçları üzerinden düşünerek zihinsel matematik yapmalarının istendiği aşamadır. Çocukların nesneler üzerinde hareket ederek somut deneyimler edinmeleri yeterli değildir. Çocuklara, geçiş dönemi işitsel ve görsel düzeyde anlayışlarını paylaşmaları için imkân sağlanmalıdır. Görsel temsillerle birlikte kullanılan gerçek nesneler, bu geçiş sırasında öğrencilere yardımcı olacaktır. Öğretmenlerin, öğrencilerin bilgiyi inşa etmelerini sağlayacak uygun rehberliği sağlamak için çocukların her bir kavram veya konu hakkındaki anlayışlarının farkında olmaları gerekir.

Sembolik Düzey: Bu düzeyde çocuklara sayı kavramları için sayılar ve matematiksel semboller $(+,-, \times,=, v b$.), sözcükler için harfler gibi zihinsel anlayışlarını temsil eden sembollerle kullanır. İlkokul öğretmenlerinin öğrencilerine zihinlerinde kafa karışıklı̆̆ yaratabilecek rakamlar, harfler ve matematiksel sembolleri tanıtarak sembolik düzeye başlamaları gerektiği ifade edilmektedir (Gallestein, 2005).

Bruner'in dile getirdiği bu üç düzeye örnek olarak manipülatiflerle fiziksel olarak matematik yapmak eylemsel; görsel, işitsel veya kinestetik ipuçları içeren temsiller üzerinden düşünerek zihinsel matematik yapmak imgesel; sayı sembollerini anlamlı olarak kullanabilmek sembolik düzeyi gösterir. Örneğin bir çocuk "6 artı 7" toplama problemini "7'yi aldım ve 7'nin $6+1$ olduğunu biliyorum. Bu yüzden 6'yı diğer 6'ya ekledim 12 buldum ve sonra 1'i ekleyince 13'ü buldum." şeklinde ifade edebiliyorsa bilgiyi sembolik düzeyde kullanmıştır. 
Bruner'e göre, çocuklar sembolik düzeye geçmeden önce hem somut deneyimler hem de görsel yaşantılarla beslenmelidir (Smith, 2001). Bu temsil düzeylerindeki sıralamada doğrusal ilişki arama her zaman doğru olmayabileceğinin altını da çizmek gerekir. Yani eylemsel düzeyde bilgi verilmeden imgesel düzeyde öğrenmenin gerçekleşmeyeceği iddia edilemez. Ancak bu teoride öğrenme sürecinin temel felsefesi öğrencilere bilimsel bilgiyi ezberletmek değil, çevrelerindeki dünyayı anlamaları için ihtiyaç duydukları bilimsel tutum, beceri ve bilgileri edinmelerine yardımcı olmaktır. Bu teoriyle "öğrenmeyi öğrenme" ve "yaparak öğrenme" kavramları daha fazla ön plana çıkacaktır (Özdem-Yılmaz \& Bilican, 2020). Öğrenme sürecinde yaparak ve yaşayarak öğrenmeye en elverişli öğretim araçlarından birisi öğretimsel etkinliklerdir (Bozkurt, 2012).

\subsection{Ders Kitapları ve Öğretimsel Etkinlikler}

Öğrenciye kazandırılması hedeflenen bilgi ve becerilerin belirlenmesinde en ulaşılabilir kaynaklardan birisi ders kitaplarıdır. Çünkü ders kitapları sınıf uygulamalarına kılavuzluk etmesi amaciyla hazırlanmaktadır (Olsher ve Even, 2014; Eisenmann ve Even, 2011; Haggarty ve Pepin, 2002). Türkiye'de uygulamakta olan öğretim programları çerçevesinde hazırlanan ders kitapları, öğrencinin öğrenme sürecinde etkin katılımcı olması ve sahip olduğu bilgi, beceri ve düşünceleri yeni deneyim ve durumlara taşımakta kullanması beklenmektedir (MEB, 2018). Bu bağlamda bu kitaplarda da yer verilen öğretimsel etkinlikler ön plana çıkmaktadır.

Etkinlik "etkin olma durumu, müessiriyet" olarak tanımlamaktadır (Türk Dil Kurumu etkinliği: TDK, 2011). Öğretim etkinlikleri, ders kapsamında belirlenen kazanım, bilgi veya becerilerin öğrencilere kazandırılmasını amaçlayan tasarlanmış kontrollü faaliyetlerdir (Bransford, Brown ve Cocking, 2000). Öğretim programları, öğrencilerin yaparak yaşayarak öğrenmenin ve süreçte aktif olmalarının önemli olduğunu vurgulamaktadır. Bu kapsamda matematik eğitiminin etkinlik temelli olarak planlanması öngörülmüştür (MEB, 2005). Ayrıca öğrencilerin gerçek hayat problemleri ve somut veya sanal nesneler aracılı̆̆ıyla akran etkileşimlerinden kendi öğrenmelerini oluşturmalarının gerekliliği vurgulanmaktadır. Diğer taraftan etkinlik uygulamalarında materyal kullanımı ve bu yolla öğretimin desteklenmesi savunulmaktadır (Henningsen ve Stein, 1997). Bu çerçevede öğrencilerin matematiğin estetik ve eğlenceli yönünü de keşfetmeleri, günlük yaşamla ilişki kurabilmeleri ve etkinlik uygulama sürecinde matematikle uğraştıklarının farkında olmalarını sağlanmasının büyük 
önem taşıdığının altı çizilmiştir (Björklund \& Ahlskog-Björkman, 2017). Bu çerçeveden bakıldığında ders kitapları ve öğretim süreçlerinde Bruner (1966)'da verilen zihinsel gelişim ilkelerinin bileşenlerinin görülebileceği en uygun kısım öğretimsel etkinliklerdir.

İlgili literatür incelendiğinde zihinsel gelişim ilkeleri üzerine bazı araştırmaların olduğu görülmektedir. Bu çalışmalardan Wiwin ve Mogi (2017), 3 boyutlu cisimlerin hacimleri konusunda 31 öğrencinin matematik öğrenmelerinde kullandıkları Bruner’in temsil biçimleri incelemiştir. Çalışmanın sonucunda öğrencilerin öğretiminde imgesel ve sembolik temsillerin kullanıldığı görülmüştür. Çekirdekçi ve Toptaş (2017), Bruner'in zihinsel gelişim ilkelerine göre her sınıf seviyelerindeki ilkokul matematik ders ve çalışma kitaplarında yer alan geometri öğrenme alanındaki etkinlikleri temsillerin dağılımı incelemişlerdir. Çalışmada, ders ve çalışma kitaplarında çoğunlukla imgesel temsil içeren etkinliklerin yer aldığı sonucuna varılmıştır. Öğrenci ders ve çalışma kitaplarında, Bruner'in bilişsel gelişim temsillerine göre eylemsel ve imgeseli içeren etkinliklere daha fazla yer verildiği bulgusuna ulaşılmıştır. Mas’ula, Fauzan, Elliza ve Darmansyah (2019), ilkokul dördüncü sınıf öğrencileri için pratik, geçerli ve etkili bir ortaya koymaya çalışmışlardır: Eylemsel-İmgesel-Sembolik Probleme Dayalı Öğrenme modeli (PBM-ENIKSI: Enactive Iconic Symbolic Problem Based Learning model). Çalışmanın değerlendirme aşamasında ilkokul dördüncü sınıf öğrencileri için PBMENIKSI aracılığıyla büyük bir grup saha testi gerçekleştirilmiştir. Uzman doğrulaması ile yapılan ürün geçerliliği sonuçlarına dayanarak, elde edilen veriler ile modeline uygun olarak 4.sınıf matematik ders kitabının üretimiyle sonuçlanmıştır. Haidar, Hutama ve Sunardi (2019), 4. sınıf matematik ders kitabında yer alan geometri öğrenme alanındaki etkinliklerin Bruner'in bilişsel gelişim temsillerine göre tasnif edilmiştir. 4.sınıf matematik ders kitabındaki geometri öğrenme alanındaki etkinliklerde \%28 oranında eylemsel, \%73 oranında imgesel ve \%56 oranında sembolik temsillerin olduğu sonucuna varılmıştır.

Literatürdeki çalışmalar incelendiğinde ders kitapları üzerine yapılan çalışmalarda (Seven, 2001; Çekirdekçi ve Toptaş 2017; Haidar ve diğerleri, 2019; Mas'ula ve diğerleri, 2019) daha çok geometri veya geometrinin alt öğrenme alanları özelinde olduğu görülmektedir. $\mathrm{Bu}$ çalışmada ise Bruner (1966)'in bilişsel gelişim dönemleri bir çerçeve olarak kullanarak 1. sınıf matematik ders kitabında verilen geometri öğrenme alanı dışındaki tüm öğrenme alanlarına dair de verilen etkinlikler bilişsel gelişim dönemleri açısından incelenmiştir. Araştırmanın amacı doğrultusunda şu sorulara cevap aranmıştır:

Year 5/ 2021, Volume-5, Issue-2 | WwW.ispecjournal.org 
- İncelenen ders kitabındaki her bir öğrenme alanında verilen etkinliklerin eylemsel, imgesel ve sembolik düzeyleri içerme durumuna göre dağılımı nasıldır?

- İncelenen ders kitabındaki her bir öğrenme alanında verilen etkinliklerin eylemsel-imgesel, eylemsel-sembolik, imgesel-sembolik ve eylemsel-imgeselsembolik düzeyleri ardışık içerme durumlarına göre dağılımı nasıldır?

Öğretmen ve öğrencilere yol göstermesi ve k1lavuzluk etmesi beklenen ders kitaplarındaki etkinliklerin bilişsel gelişim düzeylerine uygunluğunun incelemesi yönüyle de çalışmanın literatüre katkı sunması beklenmektedir. Bu çalışmayı diğer çalışmalardan farklı kılan yönü öğretim programı doğrultusunda hazırlanan ders kitabındaki sadece bir öğrenme alanına değil tüm öğrenme alanlarındaki etkinliklerin temsiller kapsamında incelenmesidir.

\section{Yöntem}

$\mathrm{Bu}$ çalışmada doküman analizi yöntemi kullanılmıştır. Doküman analizi, dokümanların sistematik bir şekilde değerlendirilmesini ve gözden geçirilmesini gerekli kılan bir yöntemdir (Bowen, 2009). Çalışma kapsamında doküman olarak 2020-2021 eğitim ve öğretim yılında devlet okullarında ders kitabı olarak kullanılan ilkokul 1. sınıf matematik ders kitabından yararlanılmıştır. Bakanlığın 2020-2021 eğitim öğretim yılında kullanımı için resmi olarak kendi web sitesinde yayınlandığı bu ders kitab1, ilkokul matematik öğretim programına (MEB, 2018) uygunluğu açısından Talim ve Terbiye Kurulu tarafindan kontrol edilmiş ve onaylanmıştır. 1. sınıf matematik öğretim programındaki alt öğrenme alanları ve incelenen etkinlik sayısı Tablo 1'de verilmiştir.

Tablo 1. Alt ögrenme alanlart ve incelenen etkinlik sayısı

\begin{tabular}{|c|c|c|c|}
\hline Öğrenme Alanı & & Alt Öğrenme alanı & Etkinlik sayıları \\
\hline \multirow{3}{*}{$\begin{array}{l}\text { Sayılar ve Sayılarla } \\
\text { İşlemler }\end{array}$} & Sayılar & Doğal Sayılar & 49 \\
\hline & \multirow{2}{*}{ Sayılarla İşlemler } & Doğal Sayılarla Toplama & 36 \\
\hline & & Doğal Sayılarla Çıkarma & 22 \\
\hline \multirow{3}{*}{ Geometri } & & Geometrik Cisimler ve Şekiller & 13 \\
\hline & & Uzamsal İlişkiler & 19 \\
\hline & & Geometrik Örüntüler & 4 \\
\hline \multirow{5}{*}{ Ölçme } & & Uzunluk Ölçme & 8 \\
\hline & & Paralarımız & 7 \\
\hline & & Zaman Ölçme & 8 \\
\hline & & Tartma & 7 \\
\hline & & Sıvı Ölçme & 4 \\
\hline Veri İşleme & & Veri Toplama ve Değerlendirme & 2 \\
\hline
\end{tabular}

Year 5/ 2021, Volume-5, Issue-2 | wWw.ispecjournal.org 
İlkokul matematik öğretim programında yer alan öğrenme alanlarının incelenen 1. sınıf matematik ders kitabındaki birlikte yapalım ve sıra sende başlıkları altında verilen toplam etkinlik sayısı; sayılar 49, sayılarla işlemlerde 58, geometride 36, ölçmede 34 ve veri işlemede 2 tanedir.

\subsection{Veri Analiz Süreci}

Araştırmada veriler betimsel olarak analiz edilmiştir. Betimsel analiz, elde edilen veriler, daha önceden belirlenen tema, kategori veya kodlar altında özetlenir ve yorumlanır. Bu tür analizler kişilerin, olayların ya da durumların profillerini tasvir etmek amacıyla yapılır. Betimsel çalışmalarda tanımlanan durum ya da olayla ilgili geniş bir ön bilgi gerekir (Robson, 2001). Bu bağlamda 1. sınıf matematik ders kitabında yer alan birlikte yapalım ve sıra sizde etkinlikleri Bruner (1966)'in çalışmasında yer alan zihinsel gelişim ilkeleri teorik çerçevesi kullanılarak analiz edilmiştir. Bu çerçeve bağlamında ders kitabında yer alan etkinlikler “Eylemsel, İmgesel ve Sembolik Temsiler” zihinsel gelişim dönemlerine göre kategorize edilmiştir. Bruner (1966)'in zihinsel gelişim dönemleri olan eylemsel-imgesel-sembolik temsiller kapsamında değerlendirilen bir örnek etkinlik analizi şöyledir:

\section{Birlikte Yapalim}

Görselleri inceleyerek nesne sayısını yazalım.
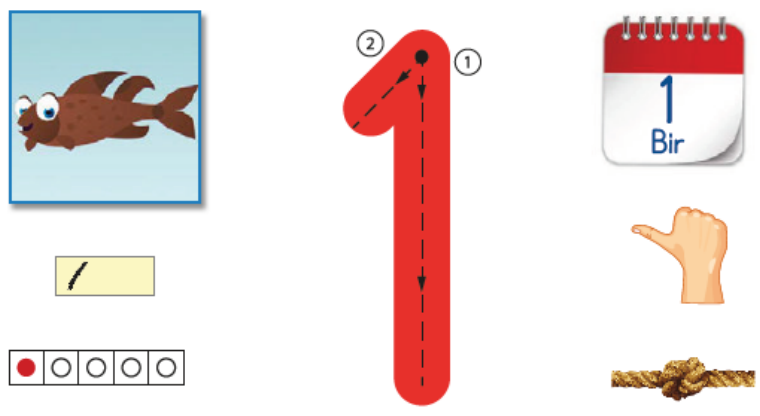

\begin{tabular}{|c|c|c|c|c|c|c|c|}
\hline 1 & $\hat{\imath}$ & $\hat{\imath}$ & $\hat{i}$ & $\hat{i}$ & $\hat{i}$ & $\hat{i}$ & $\hat{i}$ \\
\hline \hline 1 & & & & & & & \\
\hline 1 & & & & & & & \\
\hline 1 & & & & & & & \\
\hline
\end{tabular}

Şekil 1. Temsil türlerini içeren etkinlik

Şekil 1 incelendiğinde, etkinlikte öğrencilerden çizim yapılmasının istenmesi ve noktalı şeklin üzerinden kalemle geçmesi eylemsel temsillere karş1lık gelmektedir. Etkinlikte yer alan görsel materyaller ve sözel ipuçları imgesel temsilleri ifade etmektedir. "1" rakamının sembolik 
olarak tanıtılması sembolik temsil kullanımı bağlamında değerlendirilmiştir. Dolayısıyla etkinlikte yer alan matematiksel semboller ve kavramların yer alması sembolik temsillere karşılık gelmektedir. Her bir temsil türünden en az bir kriterleri sağlayan bu etkinlik eylemselimgesel-sembolik temsillerin birlikte olduğu bir türdendir.

\subsection{Güvenirlik}

Verilerin analizlerinin güvenirliği bağlamında iki araştırmacı bağımsız olarak kitapta yer alan tüm öğrenme alanları bağlamında verilen birlikte çözelim ve sıra sizde etkinliklerini zihinsel gelişim dönemleri olan eylemsel-imgesel-sembolik temsillere yönelik ayrı ayrı kodlamalar yapmışlardır. Betimsel analizlerde kullanılan çerçevede yer alan boyutlara göre araştırmacıların vermiş oldukları yanıtlar karşılaştırılarak, "Görüş Birliği” ve "Görüş Ayrılığı" olan sorular belirlenmiştir. Araştırmacıların ilgili kesitte aynı boyutu ifade etmişler ise görüş birliği, farklı seçenekleri işaretlemişlerse görüş ayrılığı olarak kabul edilmiştir. Araştırmanın güvenirliği, görüş birliği sayısı, görüş birliği ve görüş ayrılığı sayına oranlanarak hesaplanmış ve güvenirlik ortalaması hesaplanmıştır. Bu çalışma için "Uyuşum Yüzdesi” eylemselimgesel-sembolik temsiller için ortalama \%86 olarak bulunmuştur. Bu oran güvenilir olarak kabul edilmektedir (Miles \& Huberman, 1994). Elde edilen oran güvenilir olarak kabul edilmesine rağmen araştırmacılar bir araya gelmiş ve görüş ayrılığına düşülen noktalar üzerinde ortak bir görüşe varıncaya kadar tartışılmıştır. Bu şekilde veri analizinin güvenirliği artırılmıştır.

\section{Bulgular}

Matematik öğretim programına göre hazırlanmış 1.sınıf matematik ders kitabında yer alan etkinlikler zihinsel gelişim dönemleri olan eylemsel-imgesel-sembolik düzeyler bağlamında dağglımına dair elde edilen bulgular Tablo 2 'te verilmiştir.

Tablo 2. Öğrenme alanlarına göre eylemsel-imgesel-sembolik düzeylerine göre dağılımı

\begin{tabular}{lllllll}
\hline & \multicolumn{2}{l}{ Eylemsel } & İmgesel & Sembolik & $\%$ \\
\hline Sayılar & $\mathrm{N}$ & $\%$ & $\mathrm{~N}$ & $\%$ & $\mathrm{~N}$ & $96 \%$ \\
\hline Sayılarla işlemler & 43 & $88 \%$ & 48 & $98 \%$ & 47 & $100 \%$ \\
\hline Geometri & 33 & $57 \%$ & 58 & $100 \%$ & 58 & $47 \%$ \\
\hline Ölçme & 12 & $33 \%$ & 36 & $100 \%$ & 17 & $79 \%$ \\
\hline Veri & 13 & $38 \%$ & 34 & $100 \%$ & 27 & $100 \%$ \\
\hline Toplam & 2 & $100 \%$ & 2 & $100 \%$ & 2 & $84 \%$ \\
\hline
\end{tabular}


Tablo 2 incelendiğinde tüm öğrenme alanlarında imgesel düzeyler içeren etkinliklerin diğer düzey türlerini içeren etkinliklere göre daha fazla sayıda olduğu görülmektedir. Veri öğrenme alanındaki etkinliklerin diğer öğrenme alanlarda etkinliklere göre daha fazla oranda eylemsel düzeye yer verildiği söylenebilir. Sembolik düzeyi içeren etkinliklerin oranının en az geometri öğrenme alanında olduğu sonucuna varılmıştır.

Her bir öğrenme alanı ayrı ayrı ele alındığında sayılar öğrenme alanındaki etkinliklerin zihinsel gelişim düzeylerine göre dağılımı Grafik 1'de verilmiştir.

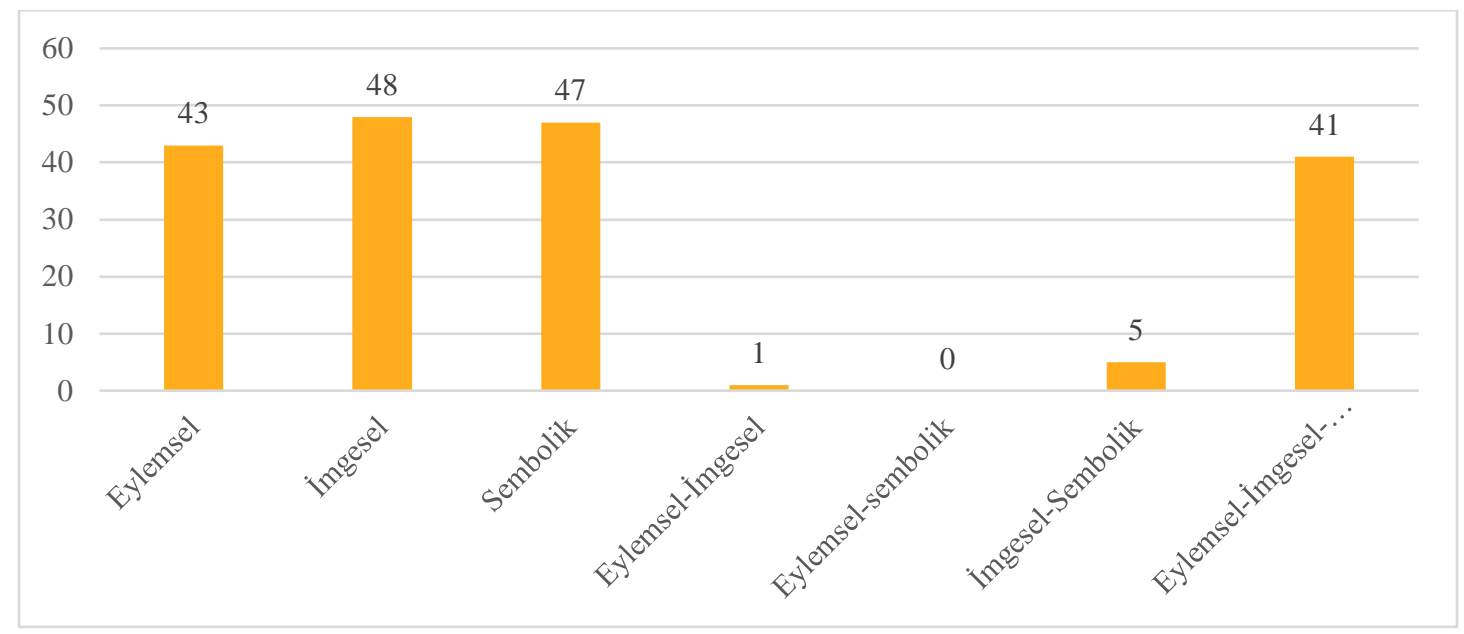

Grafik 1. Sayılar öğrenme alanındaki etkinliklerin zihinsel gelişim düzeylerine göre dă̆ılımı Grafik 1 incelendiğinde eylemsel, imgesel, sembolik ve eylemsel-imgesel-sembolik düzeyleri bir arada içeren etkinliklerin sayılarının birbirine yakın olduğu söylenebilir. Bunun yanı sıra eylemsel-imgesel düzeyleri bir arada içeren sadece bir etkinlik, eylemsel-sembolik düzeyleri bir arada içeren ise hiç etkinlik olmadığı görülmektedir.

Sayılarla işlemler öğrenme alanındaki etkinliklerin zihinsel gelişim düzeylerine göre dağılımı Grafik 2'de verilmiştir.

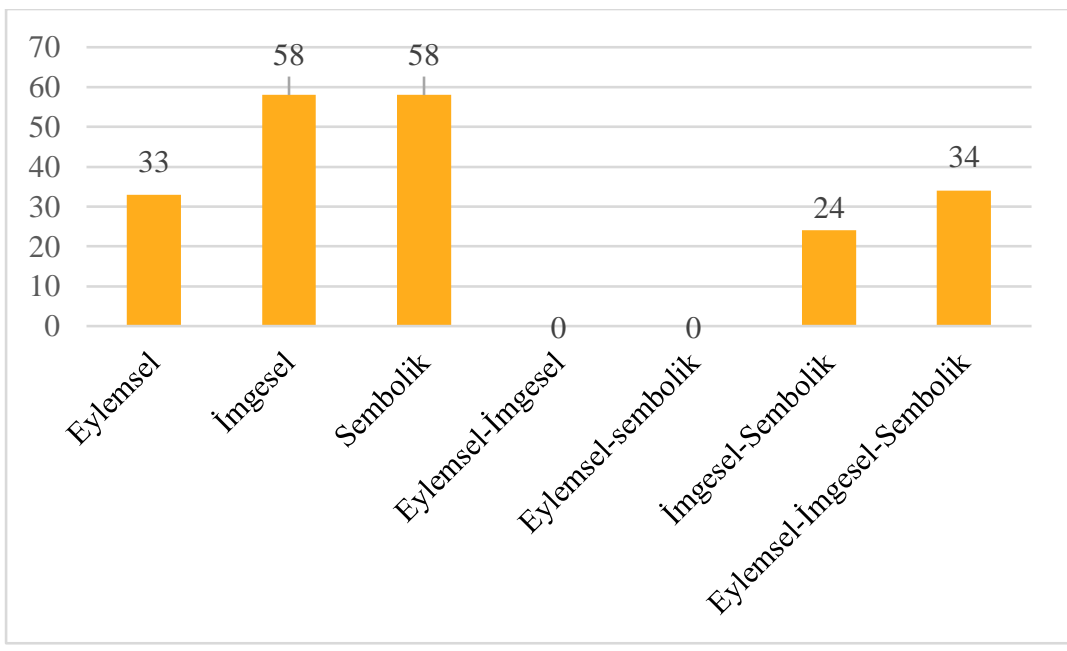


Grafik 2. Sayılarla işlemler öğrenme alanındaki etkinliklerin zihinsel gelişim düzeylerine göre dağılımı

Grafik 2 incelendiğinde İmgesel ve sembolik düzeyler içeren etkinliklerin diğer düzeyleri içeren etkinliklere göre daha fazla olduğu görülmektedir. Eylemsel-imgesel ve eylemselsembolik düzeyleri bir arada içeren etkinliklere hiç yer verilmediği görülmektedir.

Geometri öğrenme alanındaki etkinliklerin zihinsel gelişim düzeylerine göre dağılımı Grafik 3'te verilmiştir.

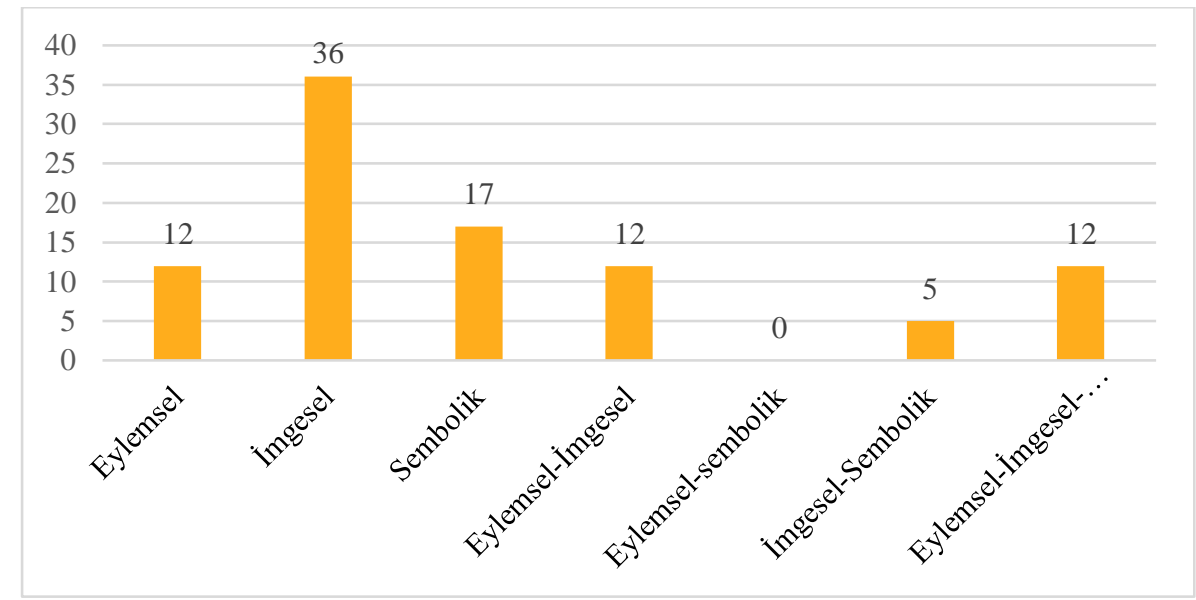

Grafik 3. Geometri öğrenme alanındaki etkinliklerin zihinsel gelişim düzeylerine göre dağglımı

Grafik 3 incelendiğinde geometri öğrenme alanındaki etkinliklerin en fazla imgesel düzeyi içerdiği görülmektedir. Bunun yanı sıra eylemsel-sembolik kodları bir arada içeren dair herhangi bir etkinliğe rastlanmamıştır.

Veri öğrenme alanındaki etkinliklerin zihinsel gelişim düzeylerine göre dağılımı Grafik 4'te verilmiştir.

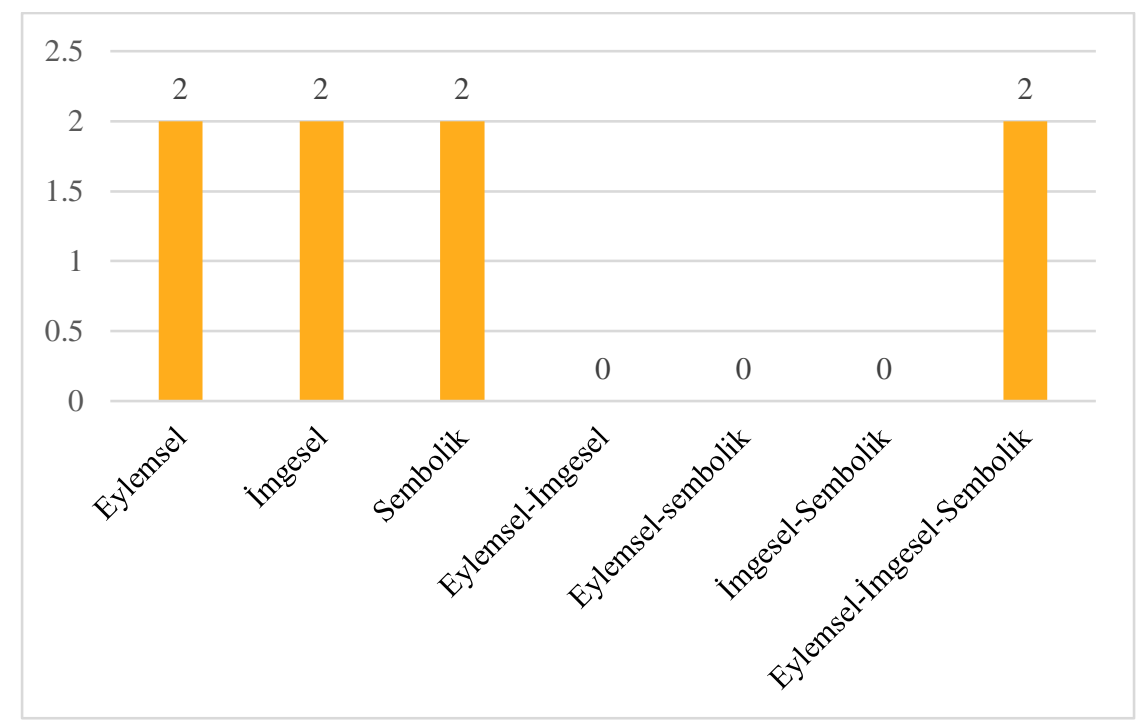

Year 5/ 2021, Volume-5, Issue-2 | WWW.ispecjournal.org 
Grafik 4. Veri öğrenme alanındaki etkinliklerin düzeylere göre dağılımı

Grafik 4 incelendiğinde veri öğrenme alanında eylemsel, imgesel, sembolik ve eylemselimgesel-sembolik düzeyleri bir arada içeren etkinliklerin aynı sayıda olduğu görülmektedir. Eylemsel-imgesel, eylemsel-sembolik ve imgesel-sembolik düzeyleri bir arada içeren hiçbir etkinliğe rastlanmamıştır.

Öğrenme alanlarına göre birden fazla düzeyi bir arada içeren etkinliklerin dağılımı Grafik 5'te verilmiştir.

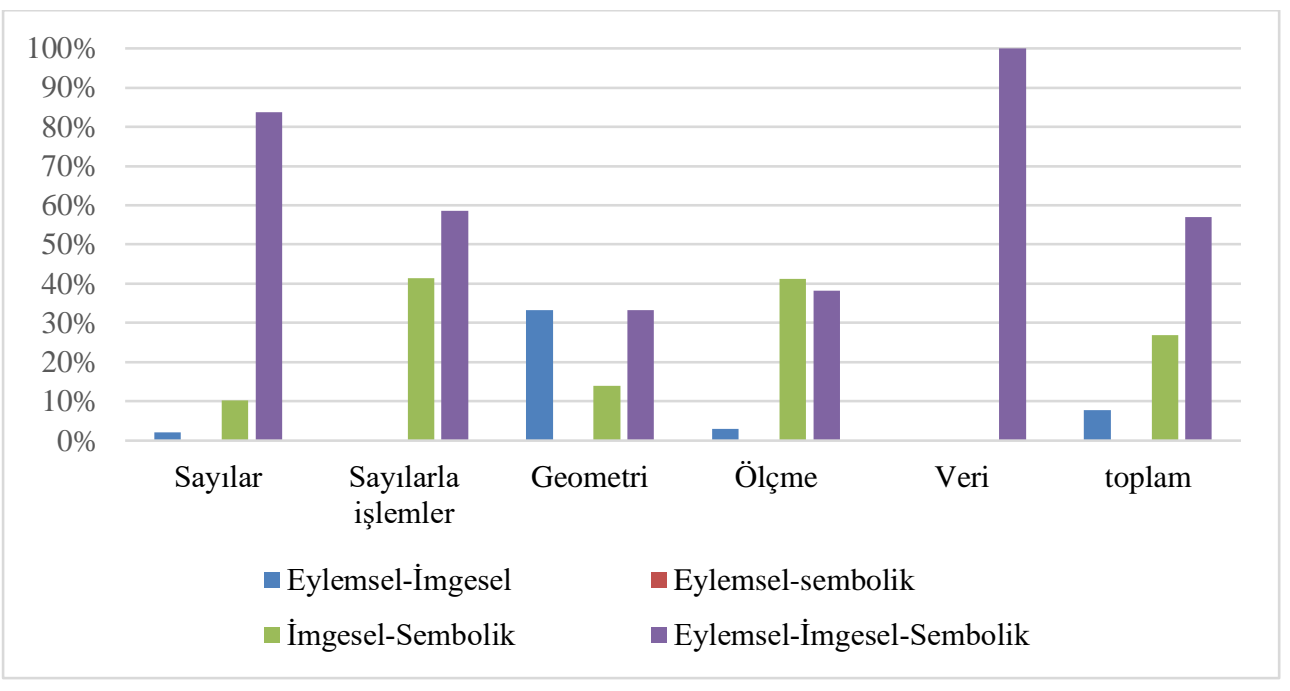

Grafik 5. Öğrenme alanlarına göre birden fazla düzeyi bir arada içeren etkinliklerin dağılımı Grafik 5 incelendiğinde etkinliklerin eylemsel-imgesel-sembolik düzeyleri bir arada içeren etkinlik sayısı diğer ikili düzey kombinasyonlarını içeren etkinlik sayısından daha fazla olduğu görülmektedir. Eylemsel-sembolik düzeylerin birlikte verildiği etkinliklere dair hiçbir etkinliğe rastlanmamıştır. Veri öğrenme alanında verilen her iki etkinlikte de eylemselimgesel-sembolik düzeylerin bir arada kullanıldığı görülmektedir. İmgesel-sembolik düzeyleri içeren en fazla etkinliğe ölçme öğrenme alanında rastlanmaktadır. Eylemsel-imgesel düzeyleri içeren etkinliklerin en fazla olduğu öğrenme alanı geometri, en az olduğu öğrenme alanı ise sayılarla işlemler öğrenme alanıdır. Bunların yanı sıra tüm öğrenme alanlarında eylemselsembolik düzeyleri bir arada içeren etkinliklere yönelik herhangi bir etkinliğe rastlanmamıştır.

\section{Tartışma}

Bu çalışmada ilkokul 1.sınıf matematik ders kitabında yer alan etkinlikler Bruner (1966)'in bilişsel gelişim düzeyleri çerçevesinde incelenmiştir. Araştırmadan elde edilen bulgulara göre tüm öğrenme alanlarında yer alan etkinliklerde imgesel temsilin diğer temsil türlerine göre daha fazla yer aldığını görülmektedir. Benzer şekilde Çekirdekçi ve Toptaş (2017) tüm sınıf Year 5/ 2021, Volume-5, Issue-2 | WWW.ispecjournal.org 
düzeyindeki ders kitaplarında imgesel temsili içeren etkinliklere daha fazla yer verildiği sonucuna ulaşmıştır. Ders kitabının hitap ettiği kitlenin ilkokul 1. Sınıf olduğu göz önüne alındığında eylemsel düzeyi içeren etkinlik sayısının daha fazla olması bu çocuklardaki psikomotor becerilerinin gelişmesine de katkı sağlayacaktır. Çünkü eylemsel düzeyde elle inşa etme ve oluşturma, el becerisini kullanma gerektirmektedir. Bu eylemlerde psikomotor becerilerin gelişimini destekleyen eylemlerdir. Ancak Özmantar, Bozkurt, Bingölbali, Demir ve Açıl (2010)'ın çalışmasına katılan 123 sınıf öğretmeninden sadece \%17'si etkinlikte materyal kullanımının eylemsel boyut olarak değerlendirilebileceğine işaret etmişlerdir. Katılımcıların çok az bir kısmının araç kullanımıyla ilgili algıları bu konuyu daha da önemli hale getirmektedir. Çünkü etkinlik konusunda araç kullanımının yeterince vurgulanmaması, araç kullanımı ve bu konunun etkinlik uygulamalarında ne denli dikkatli planlandığı konusunda soru işaretleri oluşturmaktadır.

Araştırmadan elde edilen bulgulara göre incelenen ders kitabındaki etkinliklerin daha çok imgesel ve sembolik düzeyler içerdiği görülmüştür. Benzer şekilde Olkun ve Toluk Uçar'da (2007) ilkokul öğrencilerinin matematik öğrenmedeki ihtiyaçlarının eylemsel temsile nazaran imgesel ve sembolik temsiller ile karşılandığını belirtmişlerdir. Bu durum yapılandırmacı yaklaşım bağlamında ön plana çıkan teorisyenlerin (Piaget, 1999, Kolb, 1984; Dienes, 1967 ve Bruner, 1966) düşünceleriyle çelişmektedir.

Araştırmadan elde edilen bulgulara göre geometri öğrenme alanındaki etkinliklerin diğer öğrenme alanlarına göre en az sayıda sembolik düzey içeren etkinliklerin yer aldığ1 söylenebilir. Benzer olarak Haidar, Hutama ve Sunardi (2019) 4.sınıf matematik ders kitabında geometri öğrenme alanında sembolik temsil içeren etkinliklerin oranının çok düşük olduğu sonucuna ulaşmışlardır.

Birden fazla düzey içeren etkinliklerde eylemsel-sembolik düzeylerin birlikte yer aldığı hiçbir etkinliğe rastlanmamasına nazaran eylemsel-imgesel-sembolik etkinliklerin birlikte olduğu etkinliklerin oranının yüksek olduğu sonucuna varılmıştır. Üç düzeyin bir arada kullanıldığı etkinlikler öğrencilerin kavramı çok yönlü öğrenmelerine katkıda bulunabilir. Çünkü öğrenme ilkelerinin birisi de öğrenmenin somuttan soyuta olmasının gerekliliğidir (Ocak, 2007). Bu yönüyle Bruner'in zihinsel gelişim ilkelerindeki hiyerarşik sıra bu ilkeyle örtüşmektedir. İlkokul 1. sınıf öğrencilerinin öğrenme sürecinin başında olmaları kaçınılmaz olarak hemen hemen her kazanımın onların zihinsel gelişsim açısından Bruner'in modelindeki hiyerarşik düzeylerinin en alt basamağından başlanmasının daha uygun olacağı söylenebilir. 
Ders kitapları, öğrencilerin öğrenmelerinde zihinsel gelişim düzeylerinin tamamında ilerlemelerine izin verecek şekilde, kavramları kendi başlarına yeniden oluşturarak, yapılandırarak veya tanımlayarak onların bilgi ve kavrayışlarını oluşturma firsatları sağlamalıdır.

\section{Kaynakça}

Björklund, C., \& Ahlskog-Björkman, E. (2017). Approaches to teaching in thematic work: early childhood teachers' integration of mathematics and art. International Journal of Early Years Education, 25(2), 98-111.

Bowen, G. A. (2009). Document analysis as a qualitative research method. Qualitative research journal, 9(2), 27.

Bozkurt, A. (2012). Matematik öğretmenlerinin matematiksel etkinlik kavramına dair alg1ları. Ĕgitim ve Bilim, 37(166), 101-115.

Bransford, J.D., Brown, A.L. \& Cocking, R.R. (Eds.). (2000). How people learn: brain, mind, experience, and school. Washington, DC: National Academy Press.

Bruner, J. (1966). Toward a theory of instruction. Cambridge, MA: Harvard University Press.

Bruner, J. (1996). The culture of education. Harvard University Press.

Bruner, J. S., Olver, R. R., \& Greenfield, P. M. (1966). Studies in cognitive growth. Wiley.

Çekirdekçi, S., \& Toptaş, V. (2017). Bruner'in Zihinsel Gelişim İlkelerine Göre İlkokul

Matematik Ders ve Çalışma Kitaplarında Geometri. International Journal of Education Technology and Scientific Researches, 2(2), 72-86.

Dienes, Z. P. (1967). Building up mathematics. London: Hutchinson Education.

Eisenmann, T., \& Even, R. (2011). Enacted types of algebraic activity in different classes taught by the same teacher. International Journal of Science and Mathematics Education, 9(4), 867-891.

Even, R., \& Olsher, S. (2014). Teachers as participants in textbook development: The Integrated Mathematics Wiki-book Project. In Mathematics curriculum in school education, 333-350. Springer, Dordrecht.

Gallenstein, N. L. (2005). Engaging Young Children in Science and Mathematics. Journal of Elementary Science Education, 17(2), 27-41. 
Haggarty, L., \& Pepin, B. (2002). An investigation of mathematics textbooks and their use in English, French and German classrooms: who gets an opportunity to learn what? British Educational Research Journal, 28(4), 567-590.

Haidar, D. A., Hutama, F. S., \& Sunardi, S. (2019). Analyzing The Presentation of Geometry Material Based on Bruner's Theory in Mathematics Textbook. Al-Jabar: Jurnal Pendidikan Matematika, 10(2), 271-284.

Henningsen, M. \& Stein, M.K. (1997). Mathematical tasks and student cognition: classroombased factors that support and inhibit high-level mathematical thinking and reasoning, Journal for Research in Mathematics Education, 28(5), 524-549.

Kolb, D. (1984). Experiential Learning: Experience as the Source of Learning and Development. Englewood Cliffs, NJ: Prentice Hall

Lerman, S. (1989). Constructivism, mathematics and mathematics education. Educational Studies in Mathematics, 20(2), 211-223.

Martin, D. J. (2003). Elementary science methods: A constructivist approach (3rd ed.). Albany, NY: Thomson /Wadsworth.

Mas'ula, S., \& Fauzan, A. (2019, November). Designing of Active-Iconic-Symbolic Problem

Based Learning Model (PBM-ENIKSI) for elementary school. In Journal of Physics: Conference Series (Vol. 1387, No. 1, p. 012065). IOP Publishing.

MEB (2005). İlköğretim Matematik Dersi Öğretim Programı ve Kılavuzu: 6-8. Sinıflar. Ankara: Devlet Kitapları Müdürlüğü.

Miles, M. B., \& Huberman, A. M. (1994). Qualitative data analysis: an expanded sourcebook (2. Edition) CA: Sage. Thousand Oaks.

Millî Eğitim Bakanlığı [MEB]. (2018). Ilkokul matematik dersi (1, 2, 3 ve 4. sinıflar) öğretim programı. Ankara: T.C. Millı̂ Eğitim Bakanlığı.

Ocak, G. (2007). Öğretim ilke ve yöntemleri. Ankara: Pegem A Yayıncılık.

Olkun, S. \& Toluk Uçar, Z. (2007). Ilköğretimde Etkinlik Temelli Matematik Öğretimi. Ankara: Maya Akademi.

Ozdem-Yilmaz, Y., \& Bilican, K. (2020). Discovery Learning-Jerome Bruner. In Science Education in Theory and Practice (pp. 177-190). Springer, Cham.

Özmantar, M.F., Bozkurt, A, Demir, S., Bingölbali, E., \& Açıl E. (2010). Sınıf Öğretmenlerinin 
Etkinlik Kavramına İlişkin Algıları, Selçuk Üniversitesi Ahmet Keleşoğlu Eğitim Fakültesi Dergisi, 30, 379-398.

Piaget, J. (1999). Çocukta zihinsel geliş̧im (H.Portakal, Çev.). İstanbul: Cem Yayıncıllk.

Robson, C. (2009). Real world research: a resource for social scientists and practitioner researchers. Malden, MA: Blackwell.

Şahin, İ. (2010). Curriculum assessment: Constructivist primary mathematics curriculum in Turkey. International Journal of Science and Mathematics Education, 8(1), 51-72.

Seven, S. (2001). "İlköğretim Sosyal Bilgiler Ders Kitapları Hakkında Öğretmen ve Öğrenci Görüşleri.” Yayınlanmamış Yüksek Lisans Tezi, Celal Bayar Üniversitesi Sosyal Bilimler Enstitüsü, Manisa.

Smith, S. S. (2001). Early childhood mathematics (2nd ed.). Needham Heights, MA: Allyn \& Bacon.

Steffe, L. P., \& Gale, J. E. (Eds.). (1995). Constructivism in education. Psychology Press.

TDK. Türk Dil Kurumu sözlüğü ([Online] http://tdkterim.gov.tr/bts/ adresinden 17.05.2011 tarihinde indirilmiştir.)

Wiwin, T. T., \& Mogi, Y (2017). An Analysis of Representation Forms in Learning

Mathematics on The Topic of Cubold's Volume (pp. 58-71). Proceedings the 2017 International Conference on Research in Education - Sanata Dharma University. 